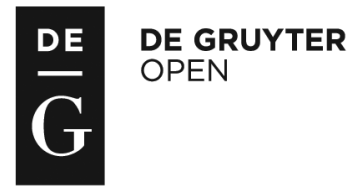

Administration, vol. 63, no. 2 (2015), pp. 119-145

doi: 10.1515/admin-2015-0013

\title{
Baby steps: The expanding financial base of local government in Ireland
}

\author{
John Considine \\ Department of Economics, University College Cork \\ Theresa Reidy \\ Department of Government, University College Cork
}

\begin{abstract}
There are two essential elements to this paper. In the first instance, we explore the specific details of revenue and expenditure trends for local authorities over the last decade. The analysis is framed against a longer-term political context of forty years which focuses especially on the weakness of local government in Ireland. Despite an official narrative of financial overdependence on central government, the comparative examination of budgetary records of local authorities reveals considerable diversity in both the revenue and expenditure patterns of authorities across the state. While some authorities are heavily reliant on central government funding, others have a much stronger base of local funding, and indeed the financial crisis since 2008 may have increased these differences. The second dimension to the research is an exploration of the impact of the great recession from 2008 on local government finance in Ireland. Using a framework of new institutionalism, we identify the crisis as another critical moment for local government. We consider the political, economic and administrative variables which have brought local government to a financial crossroads, and we explore the potential for long-lasting
\end{abstract}


financial change in local government, as well as speculating on the nature and outcome of that change.

Keywords: Local government, finance, revenue and expenditure, local property tax

\section{Introduction}

Ireland has a highly centralised system of government and indeed it has long been argued that local government in Ireland should more accurately be described as local administration, so limited are its powers. Local government's functions are usually broken down into eight categories and it has a small revenue base. Arising from their limited revenue-raising powers, local authorities have needed financial approval from central government for new initiatives, and the last forty years have witnessed a great reluctance to devolve new powers to local government despite ratification of the 1985 Council of Europe Charter of Local Self-Government and all-party support for the principle of subsidiarity. The Celtic tiger years did bring increased resources, especially in the form of development levies and capital grants, but the period was not marked by particular interest or action on reform of governance, financing or devolution of power. The economic crisis from 2008 has had an enormous impact on the financial position of all layers of government in Ireland and it has also brought a period of structural reform.

This article will provide an overview of the evolution of local government revenue and expenditure patterns over recent decades, but with the major focus on the last decade. The evidence presented here is in substantial agreement with the core theme of the research literature, which has long focused on the limited financial independence of local government. However, the overall macro picture does obscure some considerable diversity of spending and revenue-raising across local authorities, and this is explored. Attention is paid to how current spending and revenue patterns might develop as local government sees some recovery in its financial position. Local government finance is on the cusp of important financial changes. Some revenue growth is to be expected but the potential for expansion is considered in light of the sharp reductions in revenue since the beginning of the economic crisis. The Exchequer contribution to the Local Government Fund peaked at over $€ 500$ million in the mid 2000s but this was slowly reduced, and eventually replaced by the household charge and then subsequently by the local property tax in 2013 . 
The second part of the article takes a more political focus and outlines the major changes to local government financial arrangements since the 1970s. It draws from the many reports on local government over the decades and, using a framework of new institutionalism, concludes that there has been little substantive financial policy change in local government. The recent financial crisis brought important changes, notably the local property tax, but the reforms arose out of economic necessity rather than a genuine and planned attempt to develop local government in Ireland.

\section{The evolution of local government finance in Ireland}

There is considerable variation in the geographical size, population density and financial profile of local authorities across the state, and the diversity of local government is often missed in public discourse. According to the 2011 Census of Population, the population of the smallest county council is 31,798 while that of the largest city council is 527,612. Financial diversity can exaggerate the population differences. Per-person spending ranges from $€ 528$ to $€ 1,521$.

Always the lesser in Irish governance arrangements, the role of local government did expand somewhat through the 1990s, largely as a result of local and community development initiatives, usually funded through grants from the European Social Fund and the European Regional Development Fund. Nevertheless, Irish local government remains a relatively small component in the overall architecture of the Irish state. Comparative OECD data on spending by local government (as a percentage of total spending) in Ireland are listed at 11.8 per cent for 2011. This compares with local government spending in the same year of 26.7 per cent for the UK, 28.3 per cent for Iceland and 40.4 per cent for Finland. Within Europe, only Greece and Luxembourg spend less than Ireland at local government level (OECD, 2011). The share of total expenditure disbursed at local level declined during the years of the crisis (discussed in more detail later), a pattern that Ireland has in common with other European countries significantly adversely impacted by the economic crisis (see OECD, 2015).

Local government functions are spread across eight groups. These are:

1. Housing and Building;

2. Road Transport and Safety; 
3. Water Services;

4. Development Management;

5. Environmental Services;

6. Recreation and Amenity;

7. Agriculture, Education, Health and Welfare;

8. Miscellaneous Services.

Some variation can be found in the classifications used to cluster local authority services but it must be said that these classifications themselves are questionable, and in places do not reflect the actuality of the spending. Water services are being transferred to Irish Water, which in time will mean that local authorities will have a very limited role in this area. No. 7, Agriculture, Education, Health and Welfare, has become very anomalous as the administration of grant funding for third-level students is now managed centrally through the Student Universal Support Ireland (SUSI) system and local authorities do not have a substantial welfare role. The creation of the Health Services Executive (HSE) in 2005 greatly reduced the role of local government, and specifically local councillors, in the delivery of health services. No. 4, Development Management, might be expected to expand substantially as local government takes up the broader role in economic development which is outlined in the government's Putting People First policy document and reflected in the Local Government Reform Act, 2014. However, if you look at the budget subheads in this category as they currently exist, it is clear that physical development is the focus, and not economic development.

The impact of the twenty-first-century economic boom and bust on local government budgets was examined by Turley \& Flannery (2013). They compared the impact at local and central government level. They tended to focus on the changes in revenue streams for local authorities during the boom and bust. In this they noted the differential impact the boom and bust had on the different types of council because of their varying levels of dependence on central government funding. On the revenue side, our analysis extends slightly some of the analysis of Turley \& Flannery (2013) and we also draw more attention to the expenditure side of the equation.

Robbins et al. (2014) extended the analysis of the boom and bust on each city council and county council using a range of financial ratios. There were two clear messages from their research. First, there is considerable variation in the financial standing of city and county councils. Second, the largely urban councils tend to outperform the 
smaller rural councils. However, this second finding does not necessarily imply that there are economies of scale in the administration of local government in Ireland, as recent research by Callanan et al. (2014) demonstrated.

The expenditure by each type of council on the eight expenditure divisions in 2014 is presented in Table 1 (miscellaneous bodies are excluded). Almost 96 per cent of expenditure is accounted for by county councils and city councils combined, with county councils accounting for more than two-thirds of the expenditure. A glance at the figures reveals that the composition of expenditure differs substantially between county councils and city councils. Table 2 outlines the proportion of expenditure devoted to each expenditure division in 2014 by type of council.

Table 1: Expenditure by county councils, city councils, and borough \& town councils* for 2014

\begin{tabular}{cccc}
\hline All & County & City & Borough \\
$(€)$ & $(€)$ & $(€)$ & $\begin{array}{c}\text { and town } \\
(€)\end{array}$ \\
& & &
\end{tabular}

\begin{tabular}{|c|c|c|c|c|}
\hline $\begin{array}{l}\text { Housing and } \\
\text { Building }\end{array}$ & $772,527,902$ & 420,3 & $298,505,826$ & 56,72 \\
\hline $\begin{array}{l}\text { Road Transpo } \\
\text { and Safety }\end{array}$ & $827,566,229$ & $630,431,117$ & $136,377,762$ & $66,318,858$ \\
\hline Water Services & $711,884,794$ & $517,009,336$ & $185,600,113$ & $18,129,857$ \\
\hline $\begin{array}{l}\text { Development } \\
\text { Management }\end{array}$ & $285,844,597$ & $210,833,781$ & $56,470,939$ & $19,206,230$ \\
\hline $\begin{array}{l}\text { nvironmental } \\
\text { ervices }\end{array}$ & $604,999,982$ & $404,290,578$ & $248,133,215$ & $33,207,354$ \\
\hline $\begin{array}{l}\text { Recreational and } \\
\text { Amenity }\end{array}$ & $373,969,162$ & $216,444,164$ & $126,240,239$ & $37,240,462$ \\
\hline $\begin{array}{l}\text { Agriculture, } \\
\text { Education, Health } \\
\text { and Welfare }\end{array}$ & $113,708,483$ & $101,297,020$ & $11,880,362$ & 452,770 \\
\hline Total & $\begin{array}{r}482,918,696 \\
4,173,419,845\end{array}$ & $\begin{array}{r}317,081,115 \\
2,817,744,099\end{array}$ & $\begin{array}{r}121,766,993 \\
1,184,975,449\end{array}$ & $\begin{array}{r}57,781,703 \\
289,085,759\end{array}$ \\
\hline
\end{tabular}

* Town councils and borough councils were abolished in 2014 as part of a major structural reform of local government.

Note: The figures are from the 2014 Local Authority Budgets. At the time of writing the latest publicly available outturn figures are for 2012 . 
City councils spend over one-quarter of their budget (25.2 per cent) on Housing and Building whereas county councils spend 14.9 per cent on the same item. The largest item of expenditure for county councils is Road Transport and Safety. They spend 22.4 per cent of their budget on this item whereas city councils spend only 11.5 per cent of their budget on the same item. Table 2 illustrates these differences.

Table 2: Proportion of expenditure in each expenditure division by county councils, city councils, and borough \& town councils for 2014

\begin{tabular}{|c|c|c|c|c|}
\hline & All & County & City & $\begin{array}{l}\text { Borough } \\
\text { and town }\end{array}$ \\
\hline Housing and Building & 18.5 & 14.9 & 25.2 & 19.6 \\
\hline Road Transport and Safety & 19.8 & 22.4 & 11.5 & 22.9 \\
\hline Water Services & 17.1 & 18.4 & 15.7 & 6.3 \\
\hline Development Management & 6.9 & 7.5 & 4.8 & 6.6 \\
\hline Environmental Services & 14.5 & 14.4 & 20.9 & 11.5 \\
\hline Recreational and Amenity & 9.0 & 7.7 & 10.7 & 12.9 \\
\hline Agriculture, Education, Health and Welfare & 2.7 & 3.6 & 1.0 & 0.2 \\
\hline Miscellaneous Services & 11.6 & 11.3 & 10.3 & 20.0 \\
\hline
\end{tabular}

Source: Local Authority Budgets, 2014.

It could be straightforward to explain the differences in the expenditure proportions by reference to differences in the characteristics of county councils and city councils. However, it is more difficult to explain why these expenditure patterns changed so much in the ten years between 2005 and 2014 when the characteristics of city councils and county councils remained fairly similar. Table 3 presents the percentage change in expenditure between 2005 and 2014 for each council type on each item of expenditure. The changes range from an increase of 155.99 per cent for Miscellaneous Services ${ }^{1}$ in city councils to a reduction of -81.45 per cent for Agriculture, Education, Health and Welfare for the same city councils. The large changes in the Miscellaneous Services category are probably indicative of the need to revise all the categories so that they remain fit for purpose.

The direction of changes in expenditure for county councils and city councils is similar. Both show decreased expenditure on three divisions: Road Transport and Safety; Environmental Services; and

1 Local Authority Budgets list the functions included in Miscellaneous Services as financial management and rate collection, elections, courthouses, coroners and inquests, consumer protection measures, corporate estate, malicious injuries, etc. 
Table 3: Percentage change in expenditure between 2005 and 2014

\begin{tabular}{lrrrr}
\hline & All & County & City & $\begin{array}{c}\text { Borough } \\
\text { and town }\end{array}$ \\
\hline Housing and Building & 49.12 & 73.41 & 28.85 & 29.04 \\
Road Transport and Safety & -22.06 & -26.66 & -4.90 & 12.71 \\
Water Services & 32.30 & 43.15 & 39.70 & -58.86 \\
Development Management & 37.96 & 35.82 & 45.29 & 46.67 \\
Environmental Services & -24.69 & -13.01 & -13.76 & -34.71 \\
Recreational and Amenity & 18.57 & 16.26 & 27.81 & 22.31 \\
Agriculture, Education, Health & & & & \\
and Welfare & -56.77 & -48.04 & -81.45 & -88.72 \\
Miscellaneous Services & 90.82 & 85.47 & 155.99 & 67.23 \\
Total & 5.39 & 6.93 & 13.40 & 3.30 \\
\hline
\end{tabular}

Source: Local Authority Budgets, 2005, 2014.

Agriculture, Education, Health and Welfare. They show increased expenditure for the other five expenditure divisions. This suggests that there is an underlying driver of the changes. Given the changes in revenue, it is probable that the underlying change is the reduction in government grants, in particular capital grants. For both current and capital expenditure, further changes are to be expected in relation to water services. These should begin to show up in the accounts of local authorities from 2014 as service-level agreements with Irish Water are effected and the assets and management of water services are updated to reflect the creation of the new water utility.

Although the direction of change for county councils and city councils is similar there are some sizable differences in the changes since 2005. For example, county councils increased their expenditure on Housing and Building by a much greater amount than city councils over the period. However, as was shown in Table 2, city councils spend a much larger proportion of their budget on this item. This suggests that there has been a change in the proportion devoted to each item since 2005. Table 4 confirms this change. Therefore, it seems clear that the expenditure proportions are driven by revenue changes. In this context, the change in revenue that will arise from the local property tax is likely to define the roles of the local authorities.

While it is difficult to say exactly how increased revenue from the local property tax might be spent, it is possible to identify the line items that commercial rates currently fund. It could be argued that this is where the particular local authorities have greatest freedom. They could reduce such expenditure and therefore commercial rates. Their 
Table 4: Proportion of expenditure in each expenditure division by county councils and city councils, 2005 and 2014

\begin{tabular}{lrrrr}
\hline & \multicolumn{2}{c}{ County councils } & \multicolumn{2}{c}{ City councils } \\
& 2014 & 2005 & 2014 & \multicolumn{1}{c}{2005} \\
\hline Housing and Building & 14.92 & 9.20 & 25.19 & 22.17 \\
Road Transport and Safety & 22.37 & 32.62 & 11.51 & 13.72 \\
Water Services & 18.35 & 13.71 & 15.66 & 12.71 \\
Development Management & 7.48 & 5.89 & 4.77 & 3.72 \\
Environmental Services & 14.35 & 17.64 & 20.94 & 27.54 \\
Recreational and Amenity & 7.68 & 7.06 & 10.65 & 9.45 \\
Agriculture, Education, Health & & & & \\
and Welfare & 3.59 & 7.40 & 1.00 & 6.13 \\
Miscellaneous & 11.25 & 6.49 & 10.28 & 4.55 \\
Total & 100.00 & 100.00 & 100.00 & 100.00 \\
\hline
\end{tabular}

Source: Local Authority Budgets, 2005, 2014.

decisions in this regard might give an idea as to how they might spend any extra resources.

In 2014 there were seventy-seven individual line items of expenditure within the eight divisions listed in the earlier tables. Table 5 presents the top twenty line items with the largest gap between expenditure and income. For example, the second item in Table 5 shows that local authorities spent $€ 311.8$ million on the operation of fire services and recouped $€ 220.3$ million. The remainder needs to be funded by commercial rates.

The Local Government Reform Act, 2014, provided that local authorities must develop service-delivery plans consistent with the financial provisions in their annual budgets. An assessment of the service-delivery plan is to be included in the annual report of each local authority. Data from the service-delivery plans will formally document the annual service priorities of local authorities, but until this information is available, the expenditure data in Table 5 can be used as one proxy for the priorities of local authorities. Extensive cross-subsidisation implies the line items are considered important by local authorities. Another option is to list the items on which the largest amounts are spent. This is done in Table 6.

Overall, the data presented on the expenditure side point to a number of important conclusions. There is considerable variation in the expenditure patterns of city and county councils, and differences have intensified during the course of the financial crisis. The longstanding reliance on specific capital grants is especially evident in the 


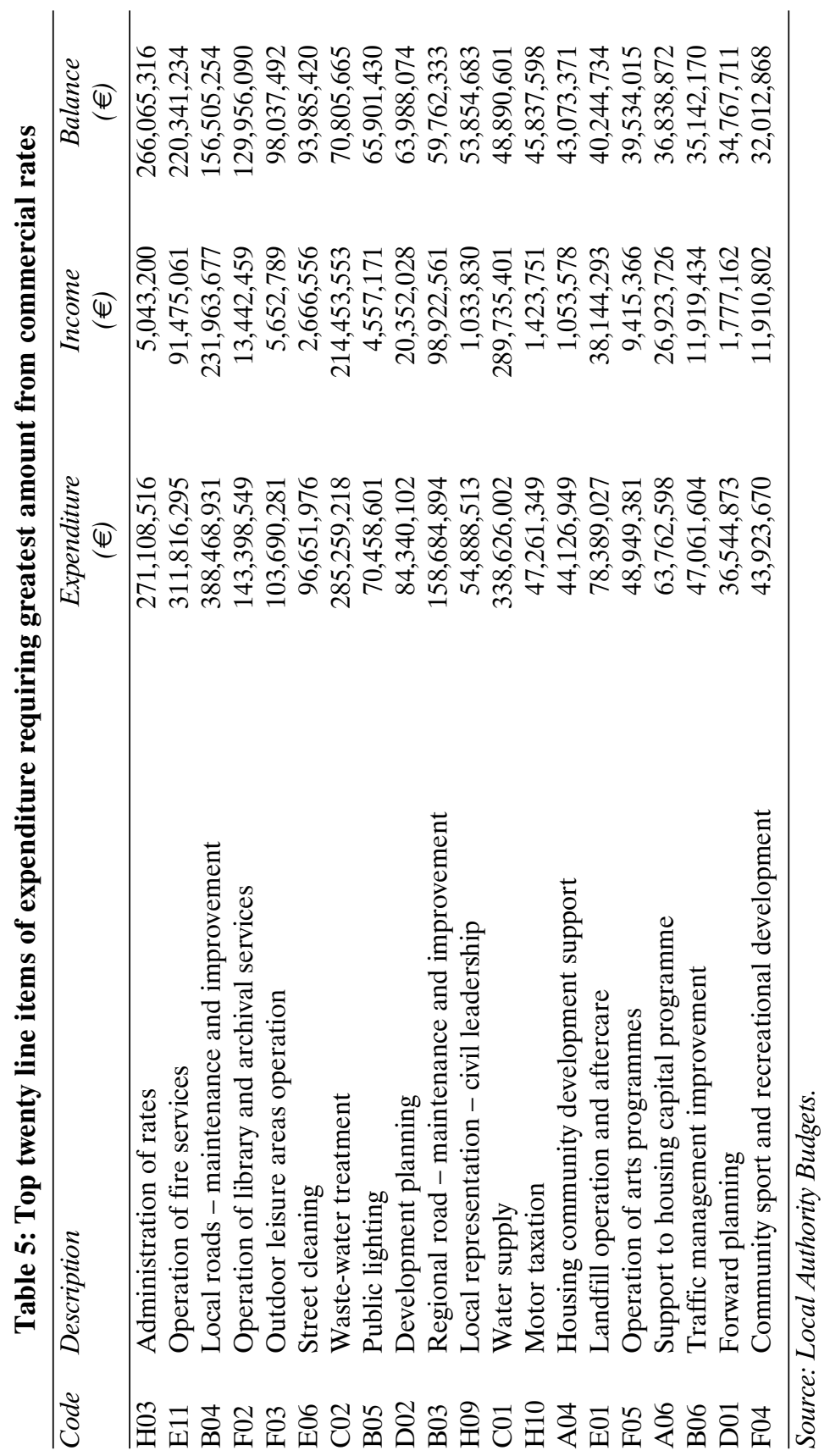


Table 6: Top twenty line items of expenditure, 2014

\begin{tabular}{llr}
\hline Code & Description & $\begin{array}{c}\text { Expenditure } \\
(€)\end{array}$ \\
\hline B04 & Local roads - maintenance and improvement & $388,468,931$ \\
C01 & Water supply & $338,626,002$ \\
E11 & Operation of fire services & $311,816,295$ \\
C02 & Waste-water treatment & $285,259,218$ \\
H03 & Administration of rates & $271,108,516$ \\
A01 & Maintenance/improvement of LA housing units & $210,181,261$ \\
A07 & RAS programme & $190,820,762$ \\
B03 & Regional road - maintenance and improvement & $158,684,894$ \\
F02 & Operation of library and archival services & $143,398,549$ \\
F03 & Outdoor leisure areas operation & $103,690,281$ \\
E06 & Street cleaning & $96,651,976$ \\
D02 & Development planning & $84,340,102$ \\
G05 & Educational support services & $81,840,353$ \\
E01 & Landfill operation and aftercare & $78,389,027$ \\
A05 & Administration of homeless service & $71,702,234$ \\
A08 & Housing loans & $70,638,428$ \\
B05 & Public lighting & $70,458,601$ \\
H11 & Agency and recoupable services & $68,149,960$ \\
A06 & Support to housing capital programme & $63,762,598$ \\
A09 & Housing grants & $59,322,094$
\end{tabular}

Source: Local Authority Budgets, 2014.

sharp drops in spending once the economic crisis began to bite. The budget categories used are outdated and becoming more so, and neither recent nor past changes to the service profile of local government are fully reflected in the labels currently used. It is not unusual in European countries to find that local government plays a major role in the delivery of health, education and welfare services. The inclusion of these labels for Irish local government is outdated and suggests a functional profile which is at odds with reality. ${ }^{2}$

Turning to the revenue side, local government has four main sources of funds. Charges for goods and services include a diverse array of payments which citizens and businesses make to local authorities for services, such as housing, parking and some waste services. Commercial rates - a type of property tax levied on commercial building - are the major source of income for many of the

2 Adopting the expenditure function categories used by organisations such as the OECD might be of some value but the restricted profile of Irish local government means that some of the entries in categories such as Education And Welfare would still be very low. 
local authorities in the country and are especially important in the large urban centres. The general purpose grant is provided by central government, as are specific grants provided for capital and current projects. The composition of local government revenues has varied quite a bit over the years, as is evidenced from the data from 2005-14 presented in Table 7, but Table 8 provides evidence of even greater variation when we look at the difference in the combination of funding sources across city and county councils.

Table 7 illustrates the changes in local government revenue in the decade since 2005 . While there was a slight (3.8 per cent) overall increase in revenue, central government funding, in the form of grants or transfers, declined dramatically. The largest decrease was in the discretionary general purpose grant, with a smaller decrease in the earmarked grants. The decline in government funding was compensated for by a 26.8 per cent increase in charges for goods and services, and by a 41.8 per cent increase in commercial rates. This effort on the part of local government was not always noticed or appreciated by the wider public.

The pension-related reduction is the amount taken from the employee in extra pension contributions introduced by the then Minister for Finance Brian Lenihan, TD. The money remains within local government rather than returning to the Exchequer Account.

Table 7: Local government revenue, 2014

\begin{tabular}{lcc}
\hline & $\begin{array}{c}2014 \\
(€)\end{array}$ & $\begin{array}{c}\text { \% change } \\
\text { from 2005 }\end{array}$ \\
\hline Government grants and subsidies & $809,563,499$ & -15.12 \\
General purpose grant & $284,283,369$ & -65.19 \\
Pension-related deductions & $74,095,688$ & \\
Goods/services & $1,490,694,062$ & 26.81 \\
Commercial rates & $1,490,145,374$ & 41.84 \\
Total & $4,148,781,992$ & 3.81 \\
\hline
\end{tabular}

Source: Local Authority Budgets, 2005, 2014.

Over 90 per cent of the revenue of local government is concentrated in the county councils and city councils. In 2014 these two forms of local government accounted for 65.2 per cent and 26.6 per cent of total revenue, respectively. Table 8 illustrates the differential impact of the changes on different types of local authorities. The figures in Table 8 reflect the unsurprising fact that city councils depend less on government grants (particularly the general purpose grant) and have a 
relatively larger base of own resources. In 2005 county councils received 53 per cent of their revenue from central government sources whereas city councils received only 28 per cent of their revenue from central government. This meant that city councils had to increase commercial rates and charges for goods/services by a smaller amount than the increase by the county councils to help make up the reduction from central government sources. These data also speak to the diversity within the sector and to the point that, while local government most certainly has limited own-source revenue, some local authorities are more independent than others.

Table 8: Percentage change between 2005 and 2014 in revenue sources by different local authority type

\begin{tabular}{lrrrc}
\hline & All & County & City & $\begin{array}{c}\text { Borough } \\
\text { and town }\end{array}$ \\
\hline Government grants and subsidies & -15.12 & -15.47 & -11.08 & -25.94 \\
General purpose grant & -65.19 & -61.57 & -81.09 & -65.94 \\
Pension-related deductions & & & & \\
Goods/services & 26.81 & 38.82 & 20.51 & -20.91 \\
Commercial rates & 41.84 & 47.00 & 31.70 & 47.61 \\
Total & 3.81 & 3.05 & 8.56 & -5.73 \\
\hline
\end{tabular}

Source: Local Authority Budgets, 2005, 2014.

The main focus of debate on local government finance has been, and continues to be, overall funding levels in local government and the reason for this is very evident from the comparative data displayed in Figure 1. Central government revenue as a percentage of total revenue is particularly high in Ireland, and correspondingly the share of total revenue raised by local government is low, and well below the EU 28 average of 11 per cent. This pattern has been stable for decades.

During the period 1995-2005, the amount of revenue collected by local authorities in Ireland actually declined as a percentage of total tax revenue. This was a time of great revenue buoyancy at national level, and Blochliger \& Rabesona (2009) demonstrated that there was a -0.2 point drop in the share of revenue collected at local level. The most recent evidence from the OECD shows that just 3.3 per cent of total tax revenue is raised by local authorities in Ireland, compared to highs of 26.7 per cent in Denmark, 35.7 per cent in Sweden and an OECD average of 10.6 per cent (Blochliger \& Nettley, 2015, p. 5). There can be a considerable time lag in the data used in international reports and an increase in the percentage of revenue collected at local levels is to be expected, especially when data from the local property 
Figure 1: Tax revenue by sub-sector, \% of total, 2012

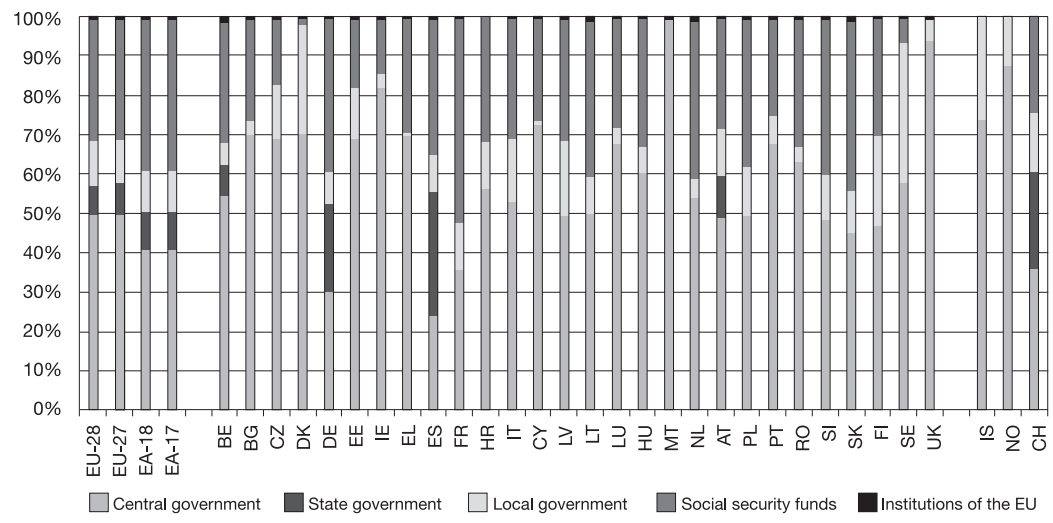

Source: Eurostat, 2015.

tax comes through, but Ireland is coming from a very low base and will remain well behind some of its European neighbours for a long time to come.

One of the important questions this paper is seeking to address is the extent to which the financial crisis may have led to changes in the overall financial position of local government. The data in Figure 1 are from 2012. There are two lines of evidence that need to be considered. First, with local government so dependent on resourcing from central government, the huge contraction in the public finances from 2008 should have been expected to manifest in significantly reduced revenues for local government. The evidence presented below will confirm that the impact on local authorities has been pro-cyclical, with budgets that contracted substantially and major reductions in expenditure. However, the second line of evidence explored is the reform movement that started in reaction to the economic crisis, some elements of which were embedded in the troika ${ }^{3}$ bailout, and were designed to expand the revenue base of all levels of government, including local government. The extent to which the reform has occurred is an important element of the evaluation of the impact of the global financial crisis on local government.

The figures in the first eight tables are taken from the Local Authority Budgets. There are two reasons for using Local Authority

${ }^{3}$ The troika bailout is the name given to the programme of financial assistance agreed with the International Monetary Fund, the European Commission and the European Central Bank in 2010. 
Budgets. First, they are used in preference to the Local Authority Annual Financial Statement Outturns because they are more up to date. The advantage of having more recent figures is somewhat offset by the fact that the figures remain budgeted figures. At times, there can be sizable differences between the budget and the outturns. These differences are documented in the Local Authority Annual Financial Statement Outturns. At the time of writing, the latest publicly available outturn figures are for 2012 (Note 17 to the accounts for 2012 documents over/under-budget amounts). In the case of 'Miscellaneous Services' the budgeted amount was $€ 456,268,537$ and the outturn was over-budget by $€ 414,287,636$ - a massive 90 per cent over-budget (Department of the Environment, Community and Local Government, 2013). While this is not the norm, it does illustrate some of the problems using the Local Authority Budgets.

The second reason for using Local Authority Budgets is that they provide greater detail on revenue and expenditure than that in the Central Statistic Office's National Income and Expenditure Accounts. For example, the 2014 Local Authority Budgets provide details on almost eighty line items of expenditure. In addition, the Local Authority Budgets decompose the receipts and expenditure by different local authority type, e.g. county councils, city councils, town councils and borough councils.

To supplement the detail in the Local Authority Budgets, we now examine the delineation of central and local government found in the National Income and Expenditure Accounts. This allows us to compare changes in central government finances with those of local government. It also allows us to compare central government funding of local government and central government funding of other areas.

We use a ten-year time frame to examine local government in the National Income and Expenditure Accounts because prior to 2005, when the HSE was formed, the financing of the Irish health system was channelled through local government via the system of health boards. The impact of this change on local government finance is illustrated in Table 9. Current receipts and expenditure of local government fell by 65 per cent in one year. Table 9 shows that receipts decreased from $€ 16.12$ billion to $€ 5.58$ billion and expenditure decreased from $€ 15.92$ billion to $€ 5.43$ billion.

In 2005 total local government receipts amounted to approximately $€ 10$ billion - with a corresponding amount of expenditure. Capital receipts amounted to 45 per cent of the $€ 10$ billion total and central government grants amounted to 60 per cent of the total. As measured 
Table 9: Local government current receipts and expenditure, nominal prices, 2004 and 2005

\begin{tabular}{lcc}
\hline & $\begin{array}{c}2004 \\
(€ m)\end{array}$ & $\begin{array}{c}2005 \\
(€ m)\end{array}$ \\
\hline Current receipts & 16,119 & 5,583 \\
Current expenditure & 15,918 & 5,430 \\
\hline
\end{tabular}

Source: Local Authority Budgets, 2004 and 2005.

by receipts and expenditure, the size of local government increased up to 2008. This increase was driven primarily by increases in capital expenditure. In the aftermath of the financial and fiscal crisis, the size of local government decreased dramatically, with the largest changes coming on the capital side of the account. Of course, it must be acknowledged that politically it is always easier to reduce capital expenditure, irrespective of the economic arguments about its longterm merits. The changes between 2005 and 2013 are captured in Figure 2.

Figure 2: Local authority receipts and expenditure, capital and current, 2005-13 $(2005=100)$

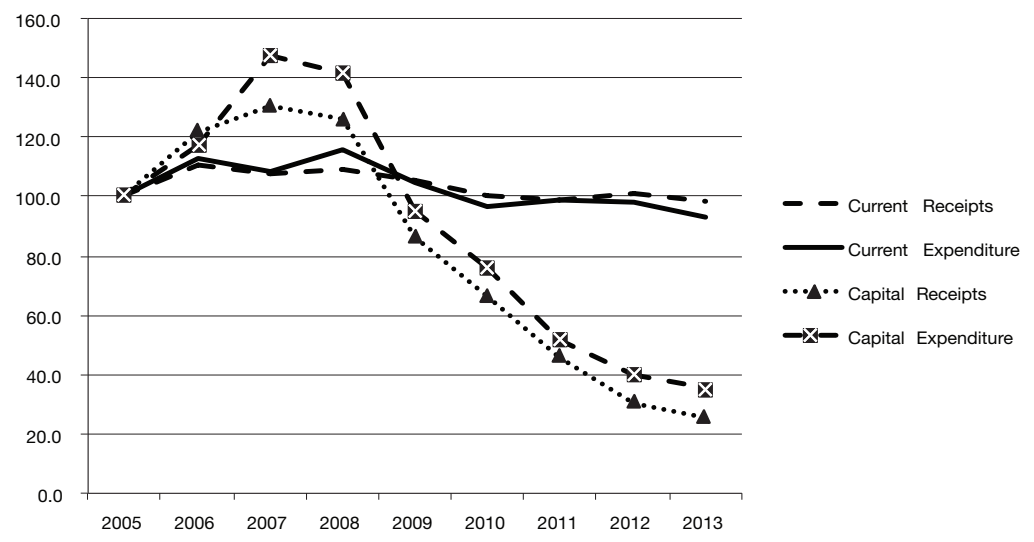

Source: National Income and Expenditure Accounts, 2005-13.

The difference for local government in the individual items of receipts and expenditure between 2005 and 2013, as classified by the National Income and Expenditure Accounts, is presented in Table 10. The decline in the absolute amounts of capital receipts/expenditure and government grants is presented. Only two items show a sizable increase, namely 'Rates and Household and NPPR Taxes' and 
'Transfer Payments'. The former is set to increase further post 2013 with the proceeds of the local property tax (discussed in more detail later).

Table 10: Local authority receipts and expenditure, 2005 and 2013

\begin{tabular}{lrr}
\hline & $\begin{array}{r}2005 \\
(€ m)\end{array}$ & $\begin{array}{r}2013 \\
(€ m)\end{array}$ \\
\hline Current receipts & 5,583 & 5,493 \\
Grants from Central Government & 2,978 & 2,340 \\
Rates and Household and NPPR Taxes & 1,052 & 1,564 \\
Other & 1,553 & 1,589 \\
& & \\
Capital receipts & 4,522 & 1,152 \\
Grants from Central Government & 3,031 & 1,033 \\
Other & 1,491 & 119 \\
& & \\
Current expenditure & 5,430 & 5,052 \\
Wages, Salaries and Pensions & 2,573 & 2,087 \\
Other Goods and Services & 1,958 & 1,708 \\
Transfer Payments & 761 & 1,133 \\
Other & 138 & 124 \\
Capital expenditure & & \\
Gross Physical Capital Formation & 4,353 & 1,549 \\
Other & 4,135 & 1,298 \\
\hline
\end{tabular}

Source: National Income and Expenditure Accounts, 2005, 2013.

The decline in funding to local government outstripped the pace of change in general non-capital expenditure by central government, and this is clear from Figure 3. A large proportion of this difference can be explained by the functional expenditure retained at central government level, e.g. social welfare. The scale of the collapse in capital funding to local government is especially clear from Figure 4 (it is important to note that the capital expenditure by central government excludes the line item used to recapitalise the banks). Overall, central funding of local government was reduced very considerably in the course of the economic crisis. There was a time lag in the initial phase of the crisis as the impact of the budget contractions at national level took at least twelve months to filter down to local government. Blochliger et al. (2010) included Ireland in their comparative analysis of fiscal policy across levels of government in the early stage of the crisis and, although they included Ireland as one of 
Figure 3: Central government non-capital grants to local government, compared to central government non-capital expenditure, 2005-13 $(2005=100)$

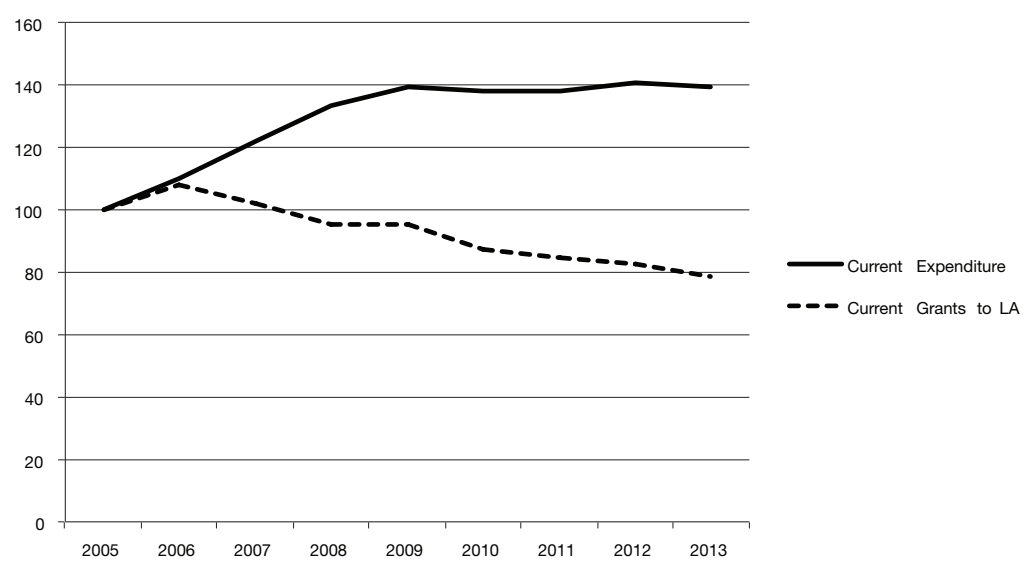

Source: National Income and Expenditure Accounts, 2005-13.

Figure 4: Central government capital grants to local government, compared to central government expenditure, 2005-13 $(2005=100)$

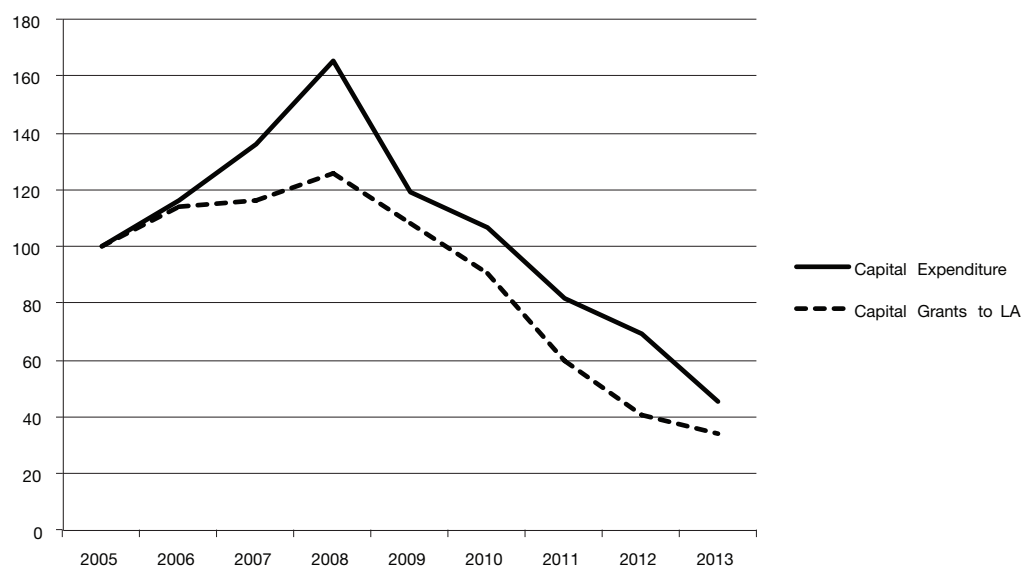

Source: National Income and Expenditure Accounts, 2005-13.

the countries where sub-central government revenue was less impacted by the crisis than central government, the evidence provided here suggests that picture is likely to change as more recent data are integrated into OECD databases. 
The revenue-raising capacity of local government is limited but, as with the expenditure side of the balance sheet, there is variation in the way in which local authorities fund themselves and again the economic crisis appears to have intensified this variation. It is also clear that central government has come to play a less important overall role in the funding of local government since the crisis. Finally, we mentioned that the expenditure classifications used for local government are outdated, and specifically the miscellaneous category appears to vary widely. Local Authority Budgets show evidence of weak financial control, with wide variance in evidence between the budgets and outturns in some cases. Weak budgetary policymaking in the Department of Finance was strongly criticised at national level (see Considine \& Reidy, 2012; Wright, 2010) but problems at local government went relatively under the radar apart from some limited media commentary. ${ }^{4}$ Weak budgetary practice combined with outdated expenditure categorisation speaks to an overall lack of administrative attention to the local government sector. A National Oversight and Audit Commission was established as part of the 2014 reform programme. It is intended the commission will scrutinise the financial practices of local authorities and it is also expected to evaluate the performance of local authorities. It remains to be seen whether this new commission will address the serious limitations in the internal practices of budgeting within local authorities.

\section{Reforming local government finance}

The financial crisis marked a turning point for all layers of government, including local government. The centralising pull of the national government, which had been markedly present since independence, was temporarily weakened as the scale of the economic crisis was realised. Basil Chubb (1992) documented the centralising tendencies of successive administrations towards local government but it is perhaps J. J. Lee who described the situation best in his 1989 classic on twentieth-century Irish history: 'The thrust of central government since independence has been to restrict the scope of local authorities and to centralise control over financial resources' (1989, p. 559). He went on to argue: 'Judged by the acid test of its behaviour, the central bureaucracy clearly regards the Irish as unfit for effective local government' (p. 562).

${ }^{4}$ For an example see Melia (2015). 
While there has been some improvement in the decades since Chubb and Lee described Irish local government, it would be wrong to describe these improvements as even modest. There was some effort to professionalise local government and the Strategic Management Initiative moved service delivery to the centre of local government functions. Yet the financial crisis begot a small but vocal political reform movement which was especially critical of the overly centralised nature of Irish governance. Its main focus was on the national institutions of government but there were strong arguments about the need to enhance local government. The extent and unexpected nature of the economic crisis reinforced the impression that politics and governance structures were overly centralised and that power elites were too concentrated, and the combination resulted in weak governance, poor oversight of policymaking and regular boom-and-bust cycles in the public finances. The confluence of economic crisis with political turbulence presented an unusual opportunity for the redesign of local government in Ireland. For the first time in several decades, significant changes were planned and implemented in the local government sector.

Using a framework of new institutionalism, this section explores the political and economic variables which account for the important changes in the financial powers of local government since the economic crisis, and it goes on to assess the likelihood of whether the current wave of reforms will translate into permanent change and the creation of a sufficient and sustainable financial base for local government. New institutionalism, specifically historical institutionalism, is a theoretical lens through which the evolution of institutions and policies can be traced (see Hall \& Taylor, 1996, for an extended discussion). In the case of local government finance in Ireland, there is strong evidence of a status quo bias, or path dependency as it is termed in the literature. Policy inertia is the dominant feature, with change infrequent despite the many reports dating back to the 1991 Local Government Reorganisation and Reform report (Advisory Expert Committee on Local Government Reorganisation and Reform, 1991), commonly known as the Barrington report. This may arise through a combination of culture, training and apathy within an institution or within the wider governance framework. Determining where, when and why change happens is part of the core of institutional theory. Specifically, Bulmer \& Burch (2001, pp. 81-2) distinguished between a critical moment and a critical juncture. A critical moment occurs when there is an opportunity for policy change which is not realised. 
Actual change is characterised as a critical juncture, which they described as 'a clear departure from previously established patterns'. Across the literature, economic crisis is identified as a causation factor for policy change (Steinmo et al., 1992). However, actual change is more likely to occur if there is a confluence of economic, political and administrative viability for the proposed new course of action.

The funding of local government appeared occasionally on the political agenda from the 1980 s to 2008 but a perusal of the many reports points to a single common conclusion: the need for greater financial autonomy. But the enthusiasm for commissioning reports was combined with political avoidance on an impressive scale as successive governments avoided implementing the main recommendation of more than thirty years of reports. The economic needs of local government were clear but there was no political will. The composition of the revenue base of local authorities did change a little over the years but change was modest, and while local authorities saw small increases in funding, they also saw their powers denuded and there is evidence of some hollowing out (see Quinlivan in this issue). Local government finance was the subject of repeated investigation by academics and consultants on behalf of, and independent of, government. The details of the individual revenue sources for local government are outlined at some length in O'Connor (2009) and they have been outlined briefly above. Domestic rates - a type of property tax - were a major element of the funding base of local government until 1978, when they were abolished arising from a controversial 1977 election promise by Fianna Fáil which they implemented once in government. This decision is often highlighted as a turning point for the financial base of local government as it eliminated an important source of revenue, which O'Connor (2009) argued was never properly replaced. The abolition of domestic rates was followed in 1984 by the ending of agricultural rates after they were struck down by a decision of the Supreme Court. A farm tax was introduced for just one year and abolished in 1987. A limited property tax (known as the residential property tax) was re-introduced in 1983 but abolished again in 1997 following much opposition. Only commercial rates have survived the years of politicking and judicial challenge.

Local government financing was the subject of periodic review and discussion (Commission on Taxation, 2009; Department of the Environment, Heritage and Local Government, 2008; Indecon International Economic Consultants, 2005; KPMG Consultants, 1996; 
National Economic and Social Council, 1985). There are many points in common across the reports but the most important point made in them all is that local government needs financial autonomy. All the studies agree on the over-reliance of local government on central government funds. Crucially, most identify a local property tax combined with some additional user charges (although local government charges and fees are not low in Ireland relative to other countries) as the best approach for providing long-term sustainable funding for local government in Ireland. In relation to additional user charges, charges for water were given regular mention.

Successive recommendations about a property tax were avoided but the Local Government (Financial Provisions) Act, 1997, did establish the Local Government Fund. Revenue from motor taxation and contributions from central government were combined in the fund, and it was intended to become a major source of revenue for local authorities thereafter. However, charges for domestic water and sewerage were removed and the general consensus was that the reforms were not sufficient to address the restricted nature of local government financing (Callanan et al., 2014; Collins \& Quinlivan, 2010; O'Connor, 2009). The Planning and Development Act, 2000, created development levies and these became an important source of revenues during the housing boom, but the revenues collapsed after 2008 , leaving local authorities in a very difficult financial position.

The local property tax drifted off the political agenda in the early 2000s and the Green Paper on local government reform published by Minister John Gormley, TD, in 2008 avoided the thorny issue of funding local government, passing the buck to the Commission on Taxation. Instead, it opted for democratic innovation and favoured the introduction of participatory budgeting as a mechanism for decisionmaking on large capital projects. As Turley \& Flannery (2013) have pointed out, there was a delayed impact of the financial crisis on the budget levels at local government but, once the trickle effect began, local authorities saw their own revenue sources fall. The sharp drop in financial support from central government is outlined in Figures 3 and 4. Development levies all but disappeared as a source of revenue during the crisis. Local government was left heavily reliant on its commercial rate base and on charges for goods and services at a time of severe economic crisis. Service cuts and staffing reductions were combined with greater efforts by local authorities to raise revenue at local level. Staff levels in local authorities have fallen by close to onequarter over the period from 2008. 
The combination of the banking crisis and the collapse in the public finances arising from the financial crisis led to the troika bailout. As is commonly the case with external financial assistance packages, the Irish bailout came with some considerable policy conditionality and ongoing surveillance. Over-reliance on revenues from the property boom (development levies in the case of local government) was identified as a major source of instability in the national public finances, and a central plank of the bailout conditionality was a requirement to broaden the tax base. As had long been argued in the studies of local government finance, Ireland was almost unique among EU countries in not having a domestic property tax. The absence of service charges for domestic water, also commonly levied at local government level internationally, meant that tax-base broadening was likely to result in changes at local government level. The specific conditions leading up to, and arising from, the economic crisis meant there was a strong economic imperative to address the public finances, and local government was always likely to be on the front line of this change given its partial financial base and unusually limited autonomy.

The long-mooted locally based property tax was back on the political agenda. The economic need for the tax was undisputed but this had been the case for decades. Political opposition to the property tax was always strong. It arose from the combination of popular opposition to domestic rates which had been poorly administered, opposition to, and eventual capitulation to, the demands to abolish the short experiment of the residential property tax, and, most important of all, an unusual underlying feature of Irish life - very high rates of property ownership (although not unique in the developed world). Nevertheless, a property tax was included in the list of policy conditions agreed in the memorandum of understanding with the troika, and for a period of time domestic political opposition to property tax was subjugated by the consequences of national bankruptcy and diminished domestic policymaking autonomy. Political viability was created.

New institutionalism also suggests that there needs to be administrative viability for a major policy change to occur. In the case of the changes introduced during the economic crisis, as with the political side, the diminished autonomy of politicians also applied to the senior civil servants and political advisors. The long-standing centralising pull so evident in public administration in Ireland was temporarily weakened as well. In practice, administrative viability presented itself through the phased introduction of the tax. Initially, a 
flat tax of $€ 100$, known as the household charge, was levied. This was managed in a mixed fashion by the local authorities themselves who were allocated responsibility for collecting the revenues via the Local Government Management Agency. It was a particularly unpopular charge but it was replaced in 2013 by a new valuation-based property tax system. Responsibility for the tax was handed to the Revenue Commissioners, who have reported compliance is in excess of 90 per cent and ahead of the targets that had been set down by government. The tax went from one where a flat rate was determined centrally and combined with local collection to one where the rate setting is decentralised (within limits set by the centre) but revenues are collected centrally.

The introduction of the local property tax was an important but minor victory for local government in Ireland. Property tax revenues are collected centrally but they are disbursed, albeit opaquely, to individual local authorities through the general purpose fund, replacing allocations which had been made into the fund from general government revenue. Local authorities in 2015 retain 80 per cent of the revenues which they generate, with the remainder retained centrally for equalisation purposes. Local government has been allocated the power to vary the rate of local property tax by up to 15 per cent within each area, but crucially central government retains the right to determine what percentage of revenue is retained within an area and what percentage is used for equalisation. While a local property tax has finally been implemented, it remains to be seen whether local authorities will be able to establish full control over its revenues. On the expenditure side, there is the fear that local authorities continue to have few (if not fewer) responsibilities, notwithstanding the extended role in economic and community development envisaged in the 2014 reforms.

The political viability needed to ensure that the property tax becomes a major funding source for local government now rests with local government itself. The initial signs are not very promising. The property tax remains very unpopular, and during the 2015 budget round many local authorities used the opportunity to reduce the rate of tax in their areas, despite an overwhelming need for investment and service-delivery improvement. This was especially the case in the urban councils of Dublin and Cork. So far, the property tax revenues are probably not enough to change the overall character of local government. Administrative viability will also come back into play. As decision-making autonomy returns to the Irish civil service, the 
centralising tendencies of the state may reassert themselves. There was very little complaint by local authorities when it was announced that 20 per cent of the property tax revenues were to be pooled centrally; this can only be expected to embolden central government.

Table 11 provides a summary of the factors which combined to create political, economic and administrative viability for the introduction of the local property tax.

Table 11: How was the local property tax finally possible?

\begin{tabular}{|c|c|c|}
\hline Economic viability & Political viability & Administrative viability \\
\hline Economic crisis & $\begin{array}{l}\text { National political } \\
\text { reform movement, } \\
\text { which highlighted } \\
\text { limitation of local } \\
\text { government as a } \\
\text { contributory factor to } \\
\text { poor governance in } \\
\text { Ireland }\end{array}$ & $\begin{array}{l}\text { Temporary weakening } \\
\text { of the long-standing } \\
\text { centralisation } \\
\text { tendencies of public } \\
\text { administration in } \\
\text { Ireland }\end{array}$ \\
\hline $\begin{array}{l}\text { Consensus on the need } \\
\text { to broaden the tax base }\end{array}$ & $\begin{array}{l}\text { Local government } \\
\text { reform included in all } \\
\text { party manifestos before } \\
\text { the } 2011 \text { election and in } \\
\text { the programme for } \\
\text { government }\end{array}$ & Phased introduction \\
\hline \multirow[t]{3}{*}{$\begin{array}{l}\text { Critical need for } \\
\text { funding for local } \\
\text { authorities }\end{array}$} & $\begin{array}{l}\text { Putting People First - } \\
\text { local government policy } \\
\text { paper indicates that } \\
\text { significant change is } \\
\text { planned with structural, } \\
\text { policy and economic } \\
\text { reforms included }\end{array}$ & \\
\hline & $\begin{array}{l}\text { Local property tax } \\
\text { included in the troika } \\
\text { memorandum of } \\
\text { understanding }\end{array}$ & \\
\hline & $\begin{array}{l}\text { Deeply unpopular but } \\
\text { reforming minister - } \\
\text { Phil Hogan, TD }\end{array}$ & \\
\hline
\end{tabular}


Property tax is but one element of the financial crisis though. Local government may have finally achieved the possibility of greater financial autonomy but the crisis also witnessed greater hollowing of local government. Here is not the place for a discussion of the controversies surrounding Irish Water but the creation of an independent agency with responsibility for the provision of the national water service was done at the expense of local authorities. They also lost out on their, albeit quite limited, role in third-level education following the creation of SUSI. The amalgamation of vocational educational committees and the creation of new education and training boards also brought a reduced role for locally elected councillors. A complete layer of local government was abolished after the 2014 local elections when town and borough councils were dissolved from the system. Arguments might well be advanced on the merits of any of these individual proposals but combined they speak to a reduced role for local authorities and a decreased need for funding.

\section{Conclusion}

There has been some change in local government over the last decade, and in the title of this article we characterise the developments as baby steps. But this article has also sought to locate more recent developments against a longer time frame, and from this perspective few of the recent changes seem to have stemmed from a coherent policy-focused plan and are nowhere near the radical overhaul of local government finance so frequently discussed in reports on local government finance.

Transfers from Europe were responsible for the 1990s expansion in funding. During the Celtic tiger boom local government saw its revenue increase and correspondingly it also spent more. However, it did this at a time when it received no substantial new functions and the data presented here suggest that this resulted in considerable variation in how the new revenues were spent. The crisis brought major contraction. Importantly, the long-needed property tax was created but the extent to which this can be bedded down in the system of local government finance is not certain. The expansion of the revenue base was urgently needed to fill a major gap created by the fall-off in central government funding. It also occurred in tandem with some minor changes in the policy functions of local government. The reform focus has been on structures. Some attention has been paid to financing and possible new powers but basic administrative improvements have not 
materialised. Outdated expenditure classifications remain and there is no sign - at least at the time of writing - that the budgetary procedures, so much criticised at national level, have received any attention. Large variance in the budget outturns suggests a need for capacity building within local government. As yet, this does not appear to be on the agenda.

The data show that there have been major developments, as judged by revenue and expenditure patterns, in local government in the last decade. Again, it is hard to see these as anything other than being forced upon local government. Even the increased resources derived from own-source income only occurred because they were forced to do so. Such changes are not always the best ones.

\section{References}

Advisory Expert Committee on Local Government Reorganisation and Reform. (1991). Local government reorganisation and reform. Dublin: The Stationery Office.

Blochliger, H., Brezzi, M., Charbit, C., Migotto, M., Pinero Campos, J. M., \& Vamalle, C. (2010). Fiscal policy across levels of government in times of crisis. OECD Working Papers on Fiscal Federalism in Times of Crisis, 12.

Blochliger, H., \& Nettley, M. (2015). Sub-central tax autonomy: 2011 update. OECD Working Papers on Fiscal Federalism, 20.

Blochliger, H., \& Rabesona, J. (2009). The fiscal autonomy of sub-central governments: An update. OECD Working Papers on Fiscal Federalism, 9.

Bulmer, S., \& Burch, M. (2001). The Europeanisation of central government: The UK and Germany in historical institutionalist perspective. In G. Schneider \& M. Aspinwall (Eds), The rules of integration: Institutionalist approaches to the study of Europe. Manchester: Manchester University Press.

Callanan, M., Murphy, R., \& Quinlivan, A. (2014). The risks of intuition: Size, costs and economies of scale in local government. The Economic and Social Review, 45 (3), 371-403.

Chubb, B. (1992) The government and politics of Ireland. UK: Pearson Education.

Collins, N., \& Quinlivan, A. (2010). Multi level governance. In J. Coakley \& M. Gallagher (Eds), Politics in the Republic of Ireland. London: Routledge. Commission on Taxation. (2009). Commission on Taxation report. Dublin: The Stationery Office.

Considine, J., \& Reidy, T. (2012). The Department of Finance. In M. MacCarthaigh \& E. O'Malley (Eds), Governing Ireland. Dublin: Institute of Public Administration. 
Department of the Environment, Community and Local Government. (2013). Local authority annual financial statement outturn 2012. Retrieved from http://www.environ.ie/en/Publications/LocalGovernment/Administration/ FileDownLoad,39591,en.pdf [15 July 2015].

Department of the Environment, Heritage and Local Government. (2008). Stronger local democracy: Options for change. Dublin: The Stationery Office.

Hall, P. A., \& Tayor, R. C. A. (1996). Political science and the three new institutionalisms. Political Studies, 44 (5), 836-957.

Indecon International Economic Consultants. (2005). Review of local government financing. Report to the Department of Environment, Heritage and Local Government. Dublin: The Stationery Office.

KPMG Consultants. (1996). The financing of local government in Ireland. Dublin: The Stationery Office.

Lee, J. J. (1989). Ireland 1912-1985: Politics and society. Cambridge: Cambridge University Press.

Melia, P. (2015, February 16). Weak financial controls in local authority system. Retrieved from http://www.independent.ie/irish-news/specialreports/weak-financial-controls-in-local-authority-system-30994823.html [15 May 2015].

National Economic and Social Council. (1985). Financing of local government in Ireland. Dublin: The Stationery Office.

O'Connor, T. (2009) Financing local government - The rating system. Department of Government Working Paper Series, 30, 1-17.

OECD. (2011). Fiscal decentralisation: Sub-central government's share in general government revenues and expenditures (2011). doi: 10.1787/gov_glance-2013-graph54-en. Retrieved from http:/www.oecdilibrary.org [15 July 2015].

OECD. (2015). Expenditures structure by level of government. In OECD, Government at a glance 2015. Paris: OECD Publishing.

Robbins, G., Turley, G., \& McNena, S. (2014). From boom to bust? The financial performance of city and county councils. Administration, 62 (1), 119-51.

Steinmo, S., Thelen, K., \& Longstreth, F. (Eds) (1992). Structuring politics: Historical institutionalism in comparative analysis. New York: Cambridge University Press.

Turley, G., \& Flannery, D. (2013). The impact of the economic boom and bust on local government budgets in Ireland. Administration, 61 (2), 33-56.

Wright, R. (2010). Strengthening the capacity of the Department of Finance. Dublin: The Stationery Office. 